Barker, P.F., Camerlenghi, A., Acton, G.D., and Ramsay, A.T.S. (Eds.)

Proceedings of the Ocean Drilling Program, Scientific Results Volume 178

\title{
25. NeOgene Record of ANTARCTIC Peninsula Glaciation in Continental RISE SEDIMENTS: ODP LEG 178, SITE $1095^{1}$
}

\author{
Carol J. Pudsey²
}

\begin{abstract}
Site 1095 is the most distal of three continental rise sites drilled during Ocean Drilling Program Leg 178. A long (600 m), near-continuous section extends from the Holocene down to nearly 10-Ma sediments, comprising fine-grained turbidites, hemipelagites, and muddy contourites. Meter-scale lithologic cyclicity is seen in sediment facies, physical properties, composition, and grain size in the upper $300 \mathrm{~m}$ of the section, representing 0-7 Ma. The diatom content of the sediments suggests sea ice was a significant limitation on productivity only during the Pleistocene. Fine grain size implies that bottom currents were never significantly stronger that at present during the last $7 \mathrm{~m} . \mathrm{y}$. The presence of ice-rafted debris implies the Antarctic Peninsula was not deglaciated for any significant period during the "warm Pliocene" (3.2-4.5 Ma). Intermittent supply of fine terrigenous sediment to the rise is consistent with published depositional models showing the ice sheet grounded to the shelf edge during glacial periods. At some times, particularly during the late Miocene, processes related to submarine channel switching and lobe progradation may have masked climatic control on deposition at this site.
\end{abstract}

1Pudsey, C.J., 2001. Neogene record of Antarctic Peninsula glaciation in continental rise sediments: ODP Leg 178, Site 1095. In Barker, P.F., Camerlenghi, A., Acton, G.D., and Ramsay, A.T.S. (Eds.), Proc. ODP, Sci. Results, 178, 1-25 [Online]. Available from World Wide Web: <http:// www-odp.tamu.edu/publications/ 178_SR/VOLUME/CHAPTERS/ SR178_25.PDF>. [Cited YYYY-MM-DD] ${ }^{2}$ British Antarctic Survey, High Cross, Madingley Road, Cambridge CB3 OET, United Kingdom. c.pudsey@bas.ac.uk

Initial receipt: 16 August 2000 Acceptance: 22 August 2001

Web publication: 4 December 2001

Ms 178SR-214 
INTRODUCTION

This paper is a contribution to the Neogene history of Antarctic Peninsula glaciation, as recorded in sediments of the continental rise, drilled during Ocean Drilling Program (ODP) Leg 178. The overall aims of the leg were given by Barker and Camerlenghi (1999). The continental rise was considered a particularly important province to drill because its fine-grained sediments contain a record of glacial history much more continuous than that on the continental shelf, which has been overridden and partly eroded many times by grounded ice. Prior to ODP drilling, the rise west of the Antarctic Peninsula had been thoroughly surveyed using single- and multichannel seismic reflection profiles, $3.5-\mathrm{kHz}$ and TOPAS acoustic profiles, and piston cores up to $11 \mathrm{~m}$ long (Rebesco et al., 1997, 1998; Canals et al., 1998; Pudsey and Camerlenghi, 1998; Pudsey, 2000). Oceanographic data including results from three near-bottom current meter moorings were also available (Camerlenghi et al., 1997; A. Camerlenghi and A. Crise, unpubl. data).

The continental rise includes a number of large mounds interpreted as sediment drifts (Rebesco et al., 1997) deposited under the influence of weak southwest-flowing bottom currents. Site 1095 on Drift 7 is the most distal of the continental rise sites, some $180 \mathrm{~km}$ from the base of the slope and only $100 \mathrm{~m}$ above the floor of the adjacent channel (Fig. F1) (Shipboard Scientific Party, 1999). A long (600 m), near-continuous section was recovered from the Holocene down to nearly 10-Ma sediments at the base. These sediments were composed of a mixture of finegrained turbidites, hemipelagites, and muddy contourites (Shipboard Scientific Party, 1999). During shipboard core description, meter-scale lithologic cyclicity was evident within many cores and some long-term depositional trends were noted over tens to hundreds of meters. Specific questions to be addressed at Site 1095 (Barker and Camerlenghi, 1999) included the following:

1. Is the present depositional system, documented from work on piston cores, a plausible analog for the older depositional environment reflected within the cored section?

2. Was deposition cyclic within the lower part of the drift section? If so, what are the cycle frequencies? And what does this cyclicity represent?

3. Can the onset of the present stage of continental glaciation (involving regular ice sheet excursions to the shelf edge) be recognized in the drift sediments? Is there a relationship between drift development and continental glacial history?

In this paper, I describe and interpret sediment composition (proportion of biogenic silica) and texture (sand percentage and grain size of the fine fraction) in the upper $300 \mathrm{~m}$ of the cored section in Drift 7, representing 0-7 Ma. The magnetostratigraphy measured during the cruise (table T38 in Shipboard Scientific Party, 1999) is used as a timescale. It is recognized that the dating for Site 1095 may improve with the completion of a magneto-biostratigraphic synthesis, but this was not available at the time of writing. Long-term trends (over several million years) and shorter-term cycles (at approximately orbital frequencies) in sediments are discussed. Although lithologic cyclicity (particularly as reflected in physical properties) includes all the sediment types recovered, sampling concentrated on the hemipelagic and contouritic parts of the section.
F1. Location map of Site 1095, p. 15.

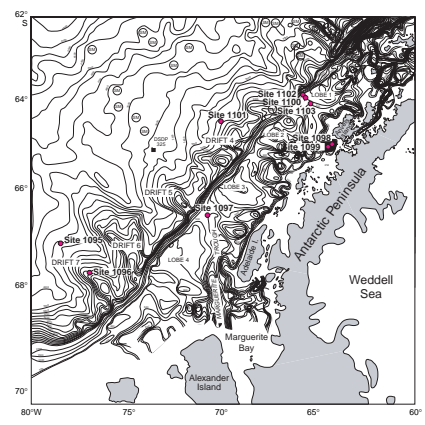


Evidence is thus adduced for paleoceanographic conditions as well as the state of glaciation of the continent.

\section{METHODS}

The cores were sampled approximately every $1.5 \mathrm{~m}$ (one sample per section). Selected intervals, where there was obvious meter-scale lithologic cyclicity, were sampled more closely (every 0.2 to $0.4 \mathrm{~m}$ ). For this study, cyclicity was delineated using a combination of shipboard core descriptions, core photographs, and physical properties, particularly magnetic susceptibility and color reflectance (Shipboard Scientific Party, 1999). As far as possible, sampling was confined to massive or bioturbated (hemipelagic) intervals, avoiding laminated sands, silts, and silty clays attributed to turbidite deposition (see below).

Sample preparation (sample size $=10 \mathrm{~cm}^{3}$ ) was carried out at the British Antarctic Survey. Biogenic silica (in the form of diatoms, radiolarians, and rare silicoflagellates) was measured by point-counting a smear slide made from each sample. This method is quick, but tends to overestimate silica compared with the true weight percentage (Pudsey, 1993; see Hillenbrand and Fütterer, Chap. 23, this volume). For textural analysis, each dried sample of $\sim 5 \mathrm{~g}$ was wet-sieved at $63 \mu \mathrm{m}(4 \phi)$ to measure sand percentage, and the sand fraction was weighed and retained. A few strewn sand-fraction slides were made to check for the presence of the radiolarian Stylatractus universus (a marker for Stage 11) in upper Quaternary sediments.

Fine fraction size distribution from 63 to $0.5 \mu \mathrm{m}(4-11 \phi)$ was measured on a Sedigraph 5100 particle size analyzer at Royal Holloway and Bedford New College, University of London. The Sedigraph determines equivalent settling diameter; bulk sediment was measured, without removal of biogenic silica, so diatoms are treated as part of the sediment. Because of their low density and porous structure, they behave hydrodynamically like grains of smaller diameter. The chosen Sedigraph output was the weight percentage within each $0.25-\phi$ interval from 4 to $11 \phi$. The very high clay content of most samples (commonly $>70 \%$ finer than $8 \phi[4 \mu \mathrm{m}]$ and $>40 \%$ finer than the measurement limit of $11 \phi$ ) necessitated extrapolation of the fine end of the cumulative frequency curves to obtain values of $\phi_{16}$ to calculate the standard grain-size parameters of sorting $\left(\sigma_{\mathrm{G}}\right)$ and skewness $\left(\mathrm{Sk}_{\mathrm{G}}\right)$ (Folk, 1974). The sand fractions were visually inspected to assess the degree of sorting, and a few representative sands were dry-sieved at 1- $\phi$ intervals.

The data for the whole recovered section are plotted against age. The data for the shorter cycles are plotted against depth as well as age, since the linear age interpolations may not be very accurate at the meter scale. The raw data are given in a data report by Pudsey (Chap. 12, this volume).

Spectral analysis was carried out on three parts of the section that showed reasonably clear (to the human eye) cyclicity in lithology and physical properties. Power spectral routines in the package MATLAB 6.1 were used; these are based on Welch's periodogram method (Welch, 1967). 


\section{SEDIMENT DESCRIPTION AND INTERPRETATION}

This section is summarized from Shipboard Scientific Party (1999). Three lithostratigraphic units were identified at Site 1095 (Fig. F2). Unit I (Holocene to late Pliocene, 0-1.77 Ma; 0.0-49.3 meters below seafloor [mbsf]) is composed of clays and silty clays, which are locally biogenic rich, contain scattered ice-rafted debris (IRD), and alternate in color between gray and brown. Unit II (late Pliocene to late Miocene, 1.77-8.93 Ma; 49.3-435.5 mbsf) is characterized by thick and repetitive sequences of greenish gray laminated silt and mud. IRD is scattered throughout Unit II and appears concentrated within bioturbated intervals. Unit III (late Miocene, $8.93-10.1 \mathrm{Ma}$; 435.5-570.2 mbsf) is mainly composed of dark greenish gray laminated claystone. Unit III will not be discussed further, as the present study only covers Unit I and part of Unit II.

\section{Unit I}

\section{Description}

Unit I is mainly composed of fine-grained brown and dark gray diatom-bearing silty clay, silty clay, and clay, with minor siliceous ooze. The sediments are indistinctly laminated and extensively bioturbated. Subunit IA consists of alternating diatom-bearing silty clay (interglacials; 0.1-0.7 $\mathrm{m}$ thick) and clay (glacials; $0.9-1.7 \mathrm{~m}$ thick), extending from the present back to marine oxygen isotope Stage 11 at $\sim 8$ mbsf. Subunit IB consists of alternating massive silty clay with sand grains (interglacials; 0.5-2.1 m thick), and clay with silt laminae (glacials; $1.3-$ $4.0 \mathrm{~m}$ thick), down to the top of a coarse-grained unit at $49.3 \mathrm{mbsf}$.

\section{Interpretation}

Unit I records deposition from suspension in a low-energy environment, as indicated by the fine grain size, lack of sorting, and absence of sedimentary structures indicating current winnowing. Slow sedimentation of the biogenic-rich facies in Subunit IA and the massive silty clay in Subunit IB allowed complete reworking by benthic burrowing organisms. In the terrigenous facies of Subunit IA, the diffuse nature of the lamination and the absence of silt laminae or graded-laminated facies suggest an origin as hemipelagites, which have been influenced by weak bottom currents (Pudsey and Camerlenghi, 1998). Dispersed sand grains and granules were transported by ice rafting.

Rare sharp-based, parallel-laminated silt laminae in Unit I are interpreted as distal turbidites.

The contact between Unit I and Unit II occurs over a 10-m-thick transitional zone, including thin layers of massive, matrix-supported diamict (Fig. F2).

\section{Unit II}

\section{Description}

Unit II is characterized by sharp-based, graded, variably laminated fine sands and silts and laminated silty clays, interbedded with massive units. Three laminated facies (L1, L2, and L3) are distinguished by the presence and abundance of very fine sand and silt laminae. A massive facies $(M)$ is characterized by the absence of primary sedimentary struc-
F2. Schematic lithostratigraphy of Site 1095, p. 16.

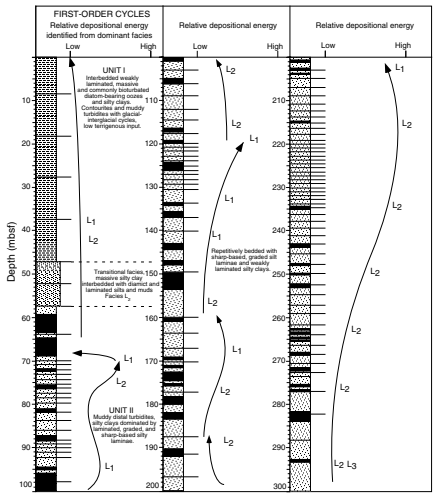


tures, except for diffuse grading, and results from hemipelagic sedimentation and intense bioturbation. Unit II shows a cyclic alternation of facies at scales from a few meters ( $\mathrm{L}$ and $\mathrm{M}$ alternations) to many tens of meters (predominance of more or less silty/sandy L facies) (Fig. F2).

Facies L1, cross-laminated sand, silt, and silty clay, comprises $\sim 10 \%$ of the thickness of Unit II. It consists of repetitive sequences of laminated to very thin-bedded fine sand and silt that grade up into laminated and massive diatom-bearing silty clay. The bases of sequences are conformable or erosional and are composed of cross-laminated very fine sand/silt, with a sharp upper contact with parallel-laminated silt and mud. This passes upward into laminated/graded silty mud, in turn overlain by massive silty clay. In some cases, muds contain sufficient diatoms to be classified as oozes. The massive silty clay shows varying degrees of bioturbation, from intense, where primary structure has been destroyed, to absent. IRD is concentrated in bioturbated bed tops.

Facies L2, parallel-laminated silt and silty clay, accounts for $\sim 70 \%$ of the total thickness of Unit II. It consists of repetitive sequences of parallel-laminated silt and mud, passing upward into laminated/graded silty mud, in turn overlain by massive diatom-bearing silty clay. Bioturbation is limited to the upper few centimeters of bed tops.

Facies L3, laminated silty clays, forms $\sim 10 \%$ of the thickness of Unit II. It consists of repetitive sequences of the thinly laminated and massive diatom-bearing silty clay that are present in the upper parts of Facies L1 and L2. Color banding is common, and upward transitions from dark to light hues within the depositional sequences suggest subtle size grading. The degree of bioturbation varies from minimal to moderate.

Facies $M$, massive, bioturbated, diatom-bearing sandy silty clay, lacks any distinct internal structure as a result of intense bioturbation. This facies accounts for $\sim 10 \%$ of Unit II. In contrast to the rather thin hemipelagic intervals of the laminated facies, the massive facies forms beds up to $1 \mathrm{~m}$ thick and is generally grayish green, in comparison with the dark greenish gray of other Unit II facies. Subtle gradations in texture are present, and beds may show a gradual upward coarsening or upward fining. IRD is common in Facies M. Bed tops are typically sharp; lower contacts are locally blurred by burrowing (typically by Planolites).

\section{Interpretation}

Sediments resembling laminated sand, silt, and mud sequences of Facies L1, L2, and L3 are well described in the literature as "parallel siltlaminated mud" (Stow and Piper, 1984), "mud turbidite" (Stow and Townsend, 1990), and "thin-bedded turbidites." These facies are characteristic of deep-sea depositional environments dominated by muddy sediment gravity flows (Pickering et al., 1988; Alonso and Maldonado, 1990). Consequently, L1, L2, and L3 are all interpreted as turbidites.

Facies $M$ probably results from slow hemipelagic settling of finegrained particles derived from various sources such as low-density turbid flows, sediment plumes following the pycnocline and transported by geostrophic flows, and biogenic productivity. Intense bioturbation indicates low deposition rates and sufficient time to allow infauna to completely mix seafloor sediments. The low carbonate and organic matter content of these sediments indicates well-oxygenated bottomwater conditions and deposition below the carbonate compensation depth. IRD is a more conspicuous component of Facies $M$ than Facies L1 to L3. This may be attributed either to a reduction in the rate of sup- 
ply of fine-grained sediment relative to the influx of IRD or to an increase in the flux of IRD.

The massive diamict beds at the top of Unit II are interbedded with laminated sediments. They may record episodes of enhanced deposition of debris from floating ice relative to background deposition of mud, or they may have originated as debris flows produced by the local resedimentation and mixing of IRD and silty clay.

The stratigraphic distribution of Facies L1, L2, and L3 shows some long-term trends, both coarsening-upward (L1 $\rightarrow$ L2 $\rightarrow$ L3; e.g., 160$120 \mathrm{~m}$ and 300-200 m) (Fig. F2) and fining-upward cycles. Facies L1 indicates higher-energy conditions or a more proximal setting to the sediment source (continental margin or local channel). Those parts of a cycle dominated by more fine-grained $\mathrm{T}_{\mathrm{D}-\mathrm{E}}$ turbidites record a more distal setting. Provisionally, first-order cycles of several tens of meters can be interpreted as recording long-term (0.5-1.5 m.y.) phases of enhanced sediment deposition, reflecting sediment supply trends and changing position and dimensions of feeder channels or lobes along the margin of the Antarctic Peninsula.

\section{Ice-Rafted Debris}

IRD is a ubiquitous component of Units I and II and locally a substantial part of the flux of terrigenous sediment to the site (see also Cowan, Chap. 10, this volume; Hassler and Cowan, Chap. 11, this volume). It occurs as scattered sand grains and granules, as isolated pebbles, and as lenses of granules and sand. IRD lithologies include volcanic (rhyolite and basalt), volcaniclastic, plutonic (granite and granodiorite), and low-grade metavolcanic rocks, which can be matched to Antarctic Peninsula sources (Hassler and Cowan, Chap. 11, this volume).

Scattered sand grains and granules are common in Unit I from 2 mbsf downward. Pebbles up to $5 \mathrm{~cm}$ in diameter include a variety of volcanic and acid to intermediate plutonic rocks, with rare, low-grade metasedimentary rocks. Most pebbles are subrounded to subangular, the largest being rounded. In general, the number of ice-rafted pebbles $(>0.5 \mathrm{~cm}$ diameter) in Unit II fluctuates but remains high until 205 mbsf. Most of these cores contain sand and granules and from one to three pebbles. From 205 to 426 mbsf, cores contain sand, granules, and low numbers of pebbles. Granite and basalt were the only pebble lithologies described from this 221-m-thick interval.

\section{LONG-TERM TRENDS IN DIATOM AND SAND ABUNDANCE}

Figure F3A shows the proportion of biogenic silica (mainly diatoms) in the upper $300 \mathrm{~m}$ of Site 1095. There are some clear long-term trends. Diatoms form $10 \%-15 \%$ of the upper Miocene sediment, increasing in the Pliocene, and peaking in abundance at $\sim 4.3 \mathrm{Ma}$. There was a slow decline in abundance and preservation through the later Pliocene, to barren sediments in the early Pleistocene. In the upper $50 \mathrm{~m}$ of section (0-1.4 Ma), diatoms are cyclically common. These trends match well with the data on percentage of opal measured by Hillenbrand and Fütterer (Chap. 23, this volume), except that the chemical technique for determination of opal tends to leach silica from clay-rich sediments.
F3. Biogenic silica and sand in the upper $300 \mathrm{~m}$ of Site 1095, p. 17.

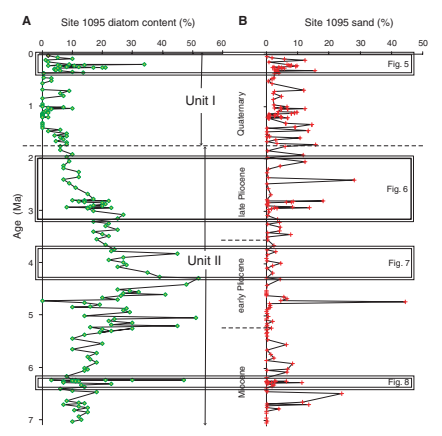


Thus, Hillenbrand and Fütterer report $~ 5 \%$ of opal in samples that appear from smear slide analysis to be barren of diatoms.

Figure F3B shows the proportion of sand (see also Wolf-Welling et al., Chap. 15, this volume). The spikiness of these data reflects the sampling of meter-scale lithologic cycles; the massive, bioturbated, hemipelagic part of each cycle tends to be sandy and the laminated, turbiditic part sand free (assuming laminated turbidite sands were not sampled) (Shipboard Scientific Party, 1999). From 7 to 1.1 Ma the low values are near zero, whereas the high values decrease from $25 \%$ at 6.5 Ma to $~ 5 \%$ at $4 \mathrm{Ma}$, then increase again. From 1.1 to $0 \mathrm{Ma}$ the low values are 3\%$4 \%$ and the peaks are up to $16 \%$.

Figure F4 shows fine fraction particle size distribution. All the samples are fine grained, with generally $60 \%-75 \%$ clay (finer than $4 \mu \mathrm{m}$ ). Unit I (Pleistocene) is the most clay-rich part of the section; the upper part of Unit II is siltier and has a coarser median diameter (Fig. F4B). Median diameter averages $9.7 \phi$ in the Pliocene and upper Miocene. Modal diameter (Fig. F4C) averages $8 \phi$ in the upper part of the section; silt modes in the medium-coarse silt range are present in some Pliocene and Miocene samples. Sorting is poor to very poor and most samples are fine skewed (Fig. F4D, F4E).

\section{SHORT-TERM “CYCLES"}

Many parts of the recovered section show approximately orbitalscale cyclicity in texture, composition, and physical properties. Selected intervals will be described from the top down, from Quaternary to upper Miocene.

\section{Late Quaternary (0-0.4 Ma)}

Marine isotope Stages 1-11 were identified in the upper $9 \mathrm{~m}$ of Holes 1095A and 1095D on the basis of lithologic description and the occurrence of the diatom Hemidiscus karstenii and the radiolarian Stylatractus universus. The lithologic cyclicity observed down to Stage 7 by Pudsey (2000) and O'Cofaigh et al. (in press) in piston cores from the other drifts, and by Lucchi et al (in press) in distal cores from Drift 7 continues in diatom percentage and silt/clay ratio down to Stage 11 (Fig. F5). Interglacials are browner in color, have lower magnetic susceptibility, and are diatom bearing, bioturbated, and sandy. Glacials are gray and almost barren of diatoms and have higher and more variable magnetic susceptibility. Glacial Stages 2-4 and the upper part of Stage 6 are laminated, but below Stage 7 both glacials and interglacials are bioturbated and contain a few percent unsorted sand (Fig. F5). Very little biogenic carbonate in the form of foraminifers or calcareous nannofossils is present at Site 1095. This contrasts with shallower sites on the drifts where carbonate contents reach $10 \%-15 \%$ in the upper part of Stages 5 and 7 (Pudsey, 2000).

\section{Late Pliocene (2-3 Ma)}

This interval consists of alternating thin bioturbated units and thicker laminated units (Fig. F6). Bioturbated units contain 3\%-20\% of unsorted sand, whereas laminated units contain $0.6 \%$ or less of wellsorted very fine sand (possibly some turbidites were inadvertently sampled). Silt laminae are sharp based and graded and vary in thickness
F4. Fine fraction particle size distribution for the upper $300 \mathrm{~m}$ of Site 1095, p. 18.

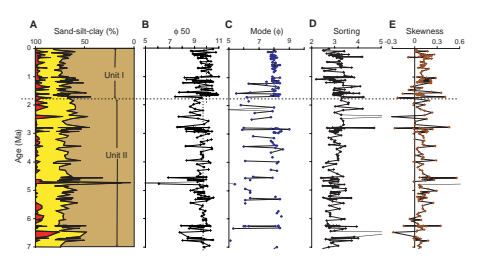

F5. Late Quaternary core log, p. 19.

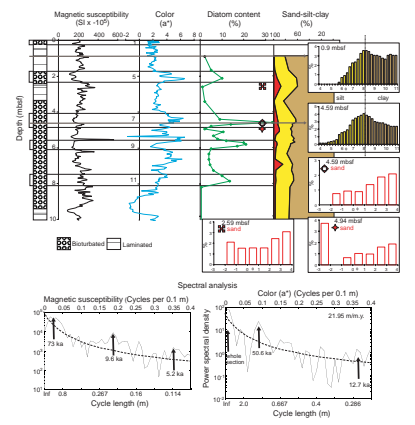

F6. Late Pliocene core log, p. 21.

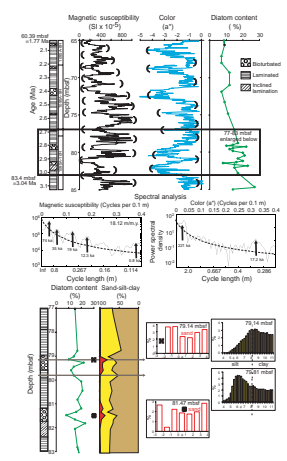


from $<1 \mathrm{~mm}$ up to $5 \mathrm{~cm}$ (most are $<1 \mathrm{~cm}$ ). Thickness and abundance variations in silt laminae have not been studied in detail. There is a gradual downcore increase in diatom percentage, but detailed data on Core $178-1095 \mathrm{~A}-10 \mathrm{H}$ show diatom percentage is not related to the alternation of sedimentary structures (Fig. F6). There is no obvious difference in diatom preservation between the bioturbated and laminated facies.

The grain-size data in Figure F6 show the bioturbated samples are sandy but deficient in coarse silt (histogram at $79.14 \mathrm{mbsf}$ ). Laminated samples, even from the fine-grained tops of turbidites, have a mode in the medium to coarse silt range (histogram at $79.81 \mathrm{mbsf}$ ). There is thus considerably more silt but less sand in the laminated facies, and the bioturbated facies cannot be derived simply from mixing of the laminated facies. This implies very marked changes in sediment supply.

The difference between the "obvious wiggles" and the results from spectral analysis of the data is discussed below.

\section{Early Pliocene (3.7-4.3 Ma)}

This interval also consists of alternating bioturbated and laminated units, but without evident (to the human eye) regular periodicity in sediment type or physical properties (Fig. F7). Bioturbated units contain $2 \%-5 \%$ of unsorted sand, whereas laminated units contain $0 \%-0.2 \%$ of well-sorted very fine sand. Silt laminae vary in thickness from $2 \mathrm{~mm}$ to $1 \mathrm{~cm}$; they have very sharp bases and sharp tops, that is, they do not grade smoothly into the overlying mud. Most are very dark gray, though very thin light gray silts occur from 110 to 110.4 and from 127.4 to 127.9 mbsf. There is a gradual downcore increase in diatom percentage, which is apparently unrelated to the alternation of sedimentary structures, with no obvious difference in diatom preservation between the facies.

Grain-size data show that muds in the laminated facies have a silt mode at $\sim 6 \phi$ (histogram at $116.51 \mathrm{mbsf}$ ) (Fig. F7). Muds in the bioturbated facies contain much more clay than in the laminated facies, in addition to the small admixture of sand.

\section{Late Miocene (6.2-6.4 Ma)}

This part of the section sees a return to cyclicity in biogenic content, with greener bioturbated units (containing up to 50\% diatoms and 11\% unsorted sand) alternating with grayer laminated units (7\%-12\% diatoms and $0 \%-0.2 \%$ sand) (Fig. F8). This cyclicity is well shown in color reflectance but is less clear in magnetic susceptibility. Note also that not all the sandy parts of the cycles are diatom rich (e.g., 239.7 mbsf). Grain-size analysis reveals a mode near the silt/clay boundary in the bioturbated samples and a weak mode in the medium silt range in the laminated samples (histograms in Fig. F8). One sample at 239.68 mbsf in a laminated (Facies L1) unit contains $11.3 \%$ of well-sorted very fine sand, exemplifying the difference between turbiditic and hemipelagic/ ice-rafted facies.

The lithologic "cyclicity" is far from regular from 235 to 300 mbsf. Sandy, green, bioturbated intervals typically $0.3-1.0 \mathrm{~m}$ thick are interbedded with gray laminated intervals $0.5-5.0 \mathrm{~m}$ thick. Using the magnetostratigraphic timescale of Shipboard Scientific Party (1999), "cycle" length ranges from 20 to 110 k.y.
F7. Early Pliocene core log, p. 23.

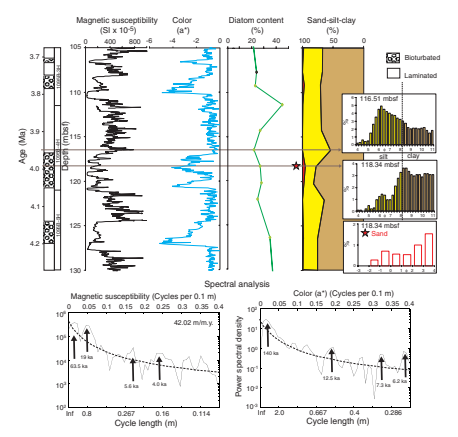

F8. Late Miocene core log, p. 25.

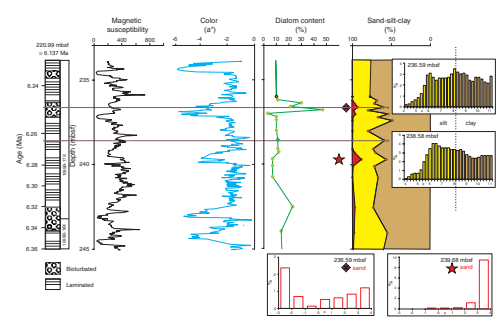




\section{DISCUSSION}

\section{Oceanography}

\section{Sea Ice and Sea-Surface Temperature}

In the upper Quaternary, there are diatoms in the interglacial samples, implying seasonally open water, whereas the barren glacials probably indicate near-permanent sea-ice cover, perhaps with intermittent polynyas (Pudsey, 2000).

In the Pliocene, diatom abundance reached a maximum at $\sim 4.3 \mathrm{Ma}$, which is consistent with the warm period in the Southern Ocean inferred by Hodell and Warnke (1991) and Bohaty and Harwood (1998). Diatoms occur throughout the cycles, suggesting that there was at least seasonally open water through glacials and interglacials. Glacial sea ice was likely of much shorter seasonal extent than in the Quaternary (Hillenbrand and Fütterer, Chap. 23, this volume). There is no evidence for anoxia, so in order to suppress bioturbation, the laminated units must have been much more rapidly deposited. This could mean deposition of each turbidite during only hours to days, with relatively long intervals between turbidity currents.

In the Miocene, generally lower diatom content in the laminated sediments, coupled with high sedimentation rates, suggests that diatom productivity was maintained throughout the cycles but that biogenic silica was diluted at the site by high terrigenous input of laminated sediment. Lower fine-grained terrigenous input during deposition of the bioturbated units increased the concentration of diatoms and ice-rafted sand as well as allowed thorough mixing of the sediment by burrowing organisms.

\section{Bottom Currents}

The fine grain size measured throughout the section down to the upper Miocene (Fig. F4) suggests that bottom currents have remained predominantly weak throughout deposition. Even the relatively sandy samples contain a considerable proportion of clay. The silts interpreted as contourites are very thin (usually 1-2 mm) (Shipboard Scientific Party, 1999) and do not have erosive bases. This implies that currents strong enough to winnow clay-size particles and deposit only silt did not persist for very long. Median grain sizes in the range of 8-11 $\phi$ (4$0.5 \mu \mathrm{m})$ and modes clustering around $8 \phi$ are consistent with bottom currents comparable to the average $6 \mathrm{~cm} / \mathrm{s}$ measured at mooring sites on Drift 7 (Camerlenghi et al., 1997). Silt modes around $6 \phi$ (Fig. F4C) were measured in samples that included a turbiditic component.

\section{Continental Glaciation}

\section{IRD Supply}

Poorly sorted or unsorted sand interpreted as ice rafted is present throughout the section, mainly in the bioturbated facies (Fig. F4). Hassler and Cowan (Chap. 11, this volume) examined over 300 gravel clasts from Sites 1096 and 1101 as well as Site 1095 and were able to match all lithologies to Antarctic Peninsula source rocks. This is relevant to the possibility suggested by Webb and Harwood (1991) that during the early Pliocene the West Antarctic Ice Sheet (including the ice 
sheet on the Antarctic Peninsula) may have disappeared completely. If this were the case and glacier ice no longer reached the coast, the supply of IRD to Site 1095 would have ceased, except perhaps for very rare clasts from distant sources in East Antarctica. It is not impossible that the ice sheet may have been very much smaller during "interglacial" parts of the depositional cycles (cf. Hall et al., 1997), but there must have been a source of sediment-laden ice not far from Site 1095 to account for the continued presence of IRD.

\section{Fine Terrigenous Supply}

The model for late Quaternary deposition on Drift 7 shows a grounded ice sheet extending to the shelf edge during glacial periods (Larter and Barker, 1991; Pudsey and Camerlenghi, 1998). The ice sheet transports sediment to the upper slope, which is very steep in this region $\left(>10^{\circ}\right)$ (Rebesco et al., 1998). Here it accumulates for only short periods before mass-flow processes transport it into deeper water. During interglacials the ice margin is at or near the present-day coast and most glacial sediment remains on the shelf. The geometry of seismic reflectors beneath the shelf and slope has been interpreted to result from similar alternating positions of the ice margin in the past (Larter et al., 1997).

According to this model, the alternation of bioturbated, sandy facies and laminated, silty facies downcore at Site 1095 could simply represent alternating interglacial and glacial conditions. If this were the case one might expect a reasonably regular cyclicity with prominent orbital periods of 19/23, 41, and $100 \mathrm{k} . \mathrm{y}$. However, real continental margin sediments probably do not respond in a linear way to climate forcings (see below). The persistence of cyclically alternating facies throughout lithologic Units I and II supports the seismic interpretation of alternating positions of the ice margin. Only in Unit III does the more uniform style of sedimentation (laminated claystone without sandy or bioturbated intervals) suggest the nature of glaciation may have been different.

\section{Orbitally Controlled vs. Autocyclic Processes}

The rather curious results from the MATLAB spectral analysis may be attributed to a less-than-ideal input function. Even if growth and decay of the Antarctic Peninsula ice sheet had been smooth and cyclic (a questionable assumption), terrigenous sediment supply to the continental rise would have increased sharply each time the ice sheet advanced to the shelf edge and, conversely, decreased each time ice retreated back over the shelf. The high sedimentation rate glacials and low sedimentation rate interglacials therefore cannot match the age model used in the frequency analysis, which is linear between paleomagnetic datum points. The simple, visual technique of counting peaks and troughs in physical properties (corresponding approximately to glacial-interglacial cycles) is actually more useful for these sediments than is a rigorous spectral analysis.

A likely complicating factor is differing amplitudes of cycles at different times in the past because of changing phase relationships in the precession, obliquity, and eccentricity forcings. During some glacials the ice sheet might not have reached the shelf edge at all or have remained there for only a short time; conversely, some interglacials might scarcely have allowed time for meltback to the coast before the next ice 
advance. This could account for cycles of regular spacing but differing thickness of the bioturbated and laminated parts of the cycles, for example, the color cycles in Figure F6. Changes in sediment supply in the late Pliocene apparently included suppression of the turbidite source, leading to the accumulation of bioturbated, sandy sediment once every $\sim 160$ k.y. (Fig. F6), plus a change in the source or concentration of magnetic mineral grains approximately every 100 k.y. (magnetic susceptibility cycles in Fig. F6). In the upper Pliocene this cyclicity is not present.

At Site 1095, which is near the distal edge of Drift 7 and has been influenced by turbidity currents flowing through the adjacent channel, processes intrinsic to a submarine channel-lobe system may also have resulted in alternation of dominantly turbiditic (laminated and rapidly deposited) and hemipelagic (bioturbated, containing IRD, and slowly deposited) facies, independent of climate forcing. On continental margins in low and mid-latitudes, seismic and core studies have documented channel avulsion with associated lobe progradation or abandonment, and these processes have commonly been inferred in ancient sedimentary successions (review by Bouma et al., 1989). Although a degree of climatic control on continental rise sedimentation is to be expected (e.g., sea level change, particularly in the Neogene), local sediment supply related to drainage basin geology and tectonic uplift may mask any orbital cyclicity.

\section{CONCLUSIONS}

1. The diatom content of the sediments suggests sea ice was only a significant limitation on productivity during the Pleistocene (1.5 Ma to present).

2. Fine grain size implies weak bottom currents throughout (7 Ma to present).

3. Presence of IRD throughout implies the Antarctic Peninsula was not deglaciated for any significant period during the "warm Pliocene."

4. Intermittent supply of fine terrigenous sediment to the rise is consistent with the depositional model showing the ice sheet grounded to the shelf edge during glacials.

5. Processes related to submarine channel switching and lobe progradation during parts of the early Pliocene and Miocene may have masked climatic control on deposition at this distal site.

Some answers may be offered to the questions listed in the "Introduction," p. 2.

1. The present depositional system is a partial analog for the older depositional environment. There is no evidence for glacialinterglacial cyclicity in sea-ice cover prior to $1.5 \mathrm{Ma}$. Bottom currents no stronger than those measured today are likely to have prevailed for at least the last 7 m.y. The cyclic provision of glacial sediment to the shelf edge did occur, but not usually at the 100k.y. period which prevailed in the late Quaternary.

2. Deposition was cyclic at least down to $300 \mathrm{mbsf}$ (7 Ma), though this does not include the "lower part of the drift section"; the sediments studied here are all within the "drift-maintenance stage" of Rebesco et al. (1997). Cycle frequencies are 100 k.y. in part of the upper Pliocene but elsewhere are shorter and irregu- 
lar. This may reflect sedimentation processes intrinsic to the shelf-slope rise depositional system, rather than purely orbital/ climatic control.

3. The onset of the present stage of continental glaciation has not been recognized in the upper $300 \mathrm{~m}$ of Site 1095. It is possible the boundary between lithologic Units II and III at 436 mbsf (Shipboard Scientific Party, 1999) may represent such a change, but this is beyond the scope of the present study.

\section{ACKNOWLEDGMENTS}

This research used samples and/or data provided by the Ocean Drilling Program (ODP). ODP is sponsored by the U.S. National Science Foundation (NSF) and participating countries under management of Joint Oceanographic Institutions (JOI), Inc. Funding for this research was provided by the Natural Environment Research Council, United Kingdom.

This work relies on the shipboard core descriptions and stratigraphic and physical properties data measured by the Leg 178 Shipboard Scientific Party. I particularly thank all the members of the sampling shifts. Steve Moreton carried out much of the sample preparation, and he and Adrian Palmer at RHBNC operated the Sedigraph. Mike Meredith kindly performed the spectral analysis. Peter Barker, David Piper, and Kari Strand provided useful comments on the manuscript. 


\section{REFERENCES}

Alonso, B., and Maldonado, A., 1990. Late Quaternary sedimentation of the Ebro turbidite systems (Northwestern Mediterranean): two styles of deep-sea deposition. Mar. Geol., 95:353-377.

Barker, P.F., and Camerlenghi, A., 1999. An Approach to Antarctic Glacial History: the Aims of Leg 178. In Barker, P.F., Camerlenghi, A., Acton, G.D., et al., 1999. Proc. ODP, Init. Repts., 178, 1-44 [CD-ROM]. Available from: Ocean Drilling Program, Texas A\&M University, College Station, TX 77845-9547, U.S.A.

Bohaty, S.M., and Harwood, D.M., 1998. Southern Ocean Pliocene paleotemperature variation from high-resolution silicoflagellate biostratigraphy. Mar. Micropal., 33:241-272.

Bouma, A.H., Normark, W.R., and Barnes, N.E., 1989. Submarine Fans and Related Turbidite Systems: Frontiers in Sedimentary Geology: New York (Springer-Verlag).

Camerlenghi, A., Crise, A., Pudsey, C.J., Accerboni, E., Laterza, R., and Rebesco, M., 1997. Ten-month observation of the bottom current regime across a sediment drift of the Pacific margin of the Antarctic Peninsula. Antarct. Sci., 9:426-433.

Canals, M., Urgeles, R., Estrada, F., and GEBRAP Team, 1998. Internal structure and seismic facies of the deep-water sediment drifts off northern Graham Land, Antarctic Peninsula: results from a very high-resolution survey. Ann. Glaciol., 27:265-267.

Folk, R.L., 1974. Petrology of Sedimentary Rocks: Austin, TX (Hemphill Publ.).

Hall, B.L., Denton, G.H., Lux, D.R., and Schluchter, C., 1997. Pliocene paleoenvironment and Antarctic ice sheet behavior: evidence from Wright Valley. J. Geol., 105:285-294.

Hodell, D.A., and Warnke, D.A., 1991. Climatic evolution of the Southern Ocean during the Pliocene epoch from 4.8 to 2.6 million years ago. Quat. Sci. Rev., 10:205214.

Larter, R.D., and Barker, P.F., 1991. Neogene interaction of tectonic and glacial processes at the Pacific margin of the Antarctic Peninsula. In Macdonald, D.I.M. (Ed.), Sedimentation, Tectonics and Eustasy: Sea-level Changes at Active Margins. Spec. Publ. Int. Assoc. Sedimentol., 12:165-186.

Larter, R.D., Rebesco, M., Vanneste, L.E., Gamboa, L.A.P., and Barker, P., 1997. Cenozoic tectonic, sedimentary and glacial history of the continental shelf west of Graham Land, Antarctic Peninsula. In Cooper, A.K., Barker, P.F., and Brancolini, G. (Eds.), Geology and Seismic Stratigraphy of the Antarctic Margin (Pt. 2). Antarct. Res. Ser., 71:1-27.

Lucchi, R.G., Rebesco, M., Caburlotto, A., Busetti., M., Colizza, E., and Fontolan, G., in press. Sedimentary processes and glacial cycles on the sediment drifts of the Antarctic Peninsula Pacific margin: preliminary results of SEDANO-II Project. N.Z. J. Geol. Geophys.

O'Cofaigh, C., Dowdeswell, J.A., and Pudsey, C.J., 2001. Late Quaternary iceberg-rafting along the Antarctic Peninsula continental rise and in the Weddell and Scotia seas. Quat. Res., 56:308-321.

Pickering, K.T., Hiscott, R., and Hein, F.J., 1988. Deep-marine Environments: Clastic Sedimentation and Tectonics: London (Unwin Hyman).

Pudsey, C.J., 1993. Calibration of a point-counting technique for estimation of biogenic silica in marine sediments. J. Sediment. Petrol., 63:760-762.

- 2000. Sedimentation on the continental rise west of the Antarctic Peninsula over the last three glacial cycles. Mar. Geol., 167:313-338.

Pudsey, C.J., and Camerlenghi, A., 1998. Glacial-interglacial deposition on a sediment drift on the Pacific margin of the Antarctic Peninsula. Antarct. Sci., 10:286308.

Rebesco, M., Camerlenghi, A., and Zanolla, C., 1998. Bathymetry and morphogenesis of the continental margin west of the Antarctic Peninsula. Terra Antart., 5:715-728. 
Rebesco, M., Larter, R.D., Barker, P.F., Camerlenghi, A., and Vanneste, L.E., 1997. The history of sedimentation on the continental rise west of the Antarctic Peninsula. In Barker, P.F., and Cooper, A.K. (Eds.), Geology and Seismic Stratigraphy of the Antarctic Margin (Pt. 2). Am. Geophys. Union, Antarctic Res. Ser., 71:29-50.

Shipboard Scientific Party, 1999. Site 1095. In Barker, P.F., Camerlenghi, A., Acton, G.D., et al., Proc. ODP, Init. Repts., 178, 1-173 [CD-ROM]. Available from: Ocean Drilling Program, Texas A\&M University, College Station, TX 77845-9547, U.S.A.

Stow, D.A.V., and Piper, D.J.W., 1984. Deep-water fine-grained sediments: facies models. In Stow, D.A.V., and Piper, D.J.W. (Eds.), Fine-Grained Sediments: Deep-Water Processes and Facies. Spec. Publ.[0151]Geol. Soc. London, 15:611-645.

Stow, D.A.V., and Townsend, M.R., 1990. X-ray techniques and observations on distal Bengal Fan sediments cored during Leg 116. In Cochran, J.R., Stow, D.A.V., et al., Proc. ODP, Sci. Results, 116: College Station, TX (Ocean Drilling Program), 5-14.

Webb, P.-N., and Harwood, D.M., 1991. Late Cenozoic glacial history of the Ross Embayment, Antarctica. In Cronin, T.M., and Dowsett, H.J. (Eds.), Pliocene Climates. Quat. Sci. Rev., 10:215-223.

Welch, P.D., 1967. The use of fast Fourier transform for the estimation of power spectra: a method based on time averaging over short, modified periodograms. IEEE Trans. Audio Electroacoust., AU-15:70-74. 


\section{C.J. Pudsey}

NeOgene GLaciation Record

Figure F1. Location map of Site 1095 on the continental rise.

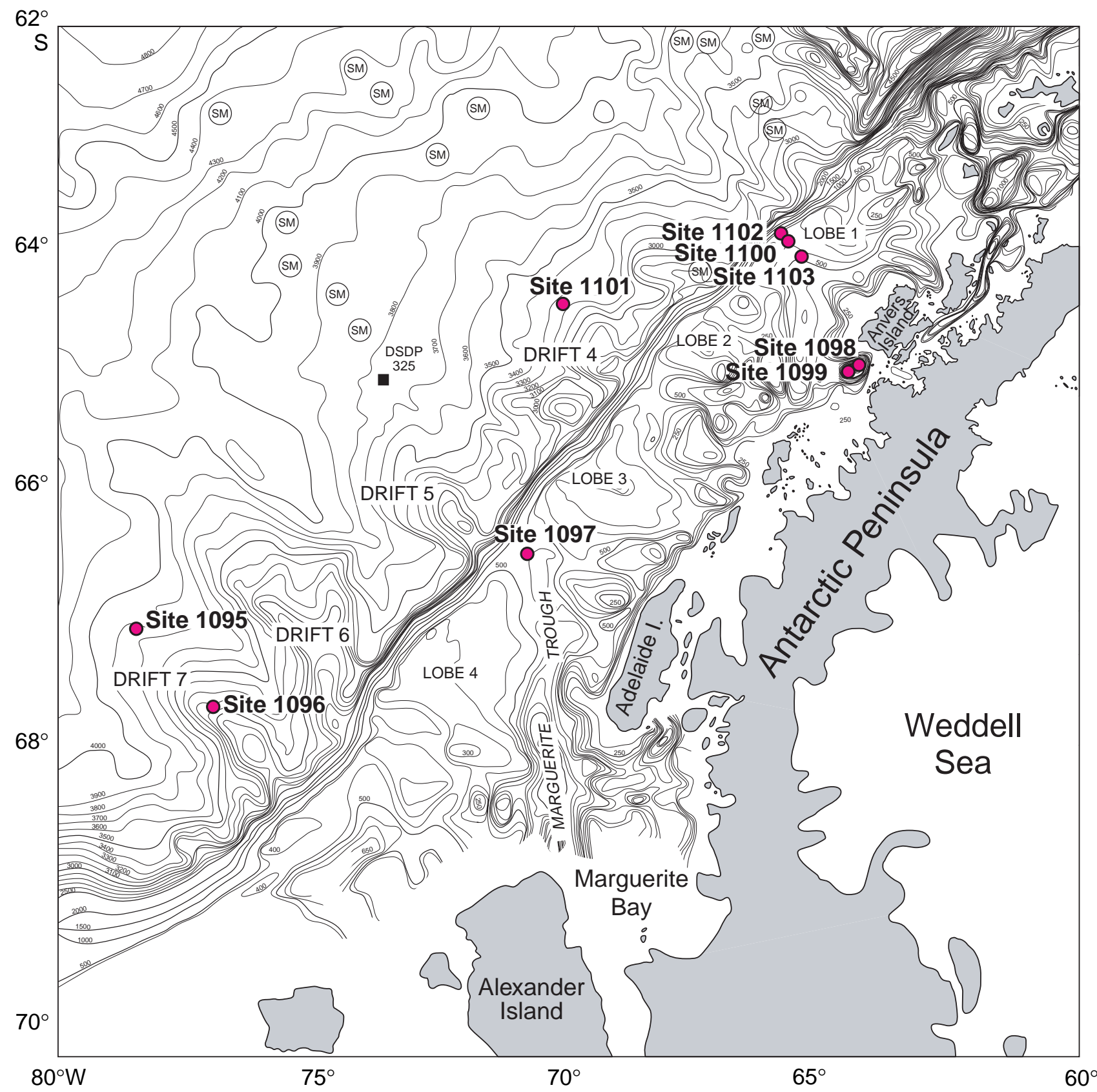




\section{C.J. Pudsey}

NeOgene GLaciation Record

Figure F2. Schematic lithostratigraphy of Site 1095 showing lithologic Units I and II, main bioturbated intervals (black), and distribution of laminated (mainly turbidite) Facies L1, L2, and L3. Horizontal lines indicate occurrence of silt laminae, which can form as much as 10\% of the section (e.g., 70-80 and 220-235 mbsf). Curved arrows show broad trends in frequency of sand and silt laminations and facies types, which are attributed to long-term "first-order" cycles in Unit II. Shorter-term, "second-order" cycles, interpreted as glacial-interglacial cycles, are defined top and bottom by intensely bioturbated intervals. These climatically driven cycles are superimposed on the long-term cycles.

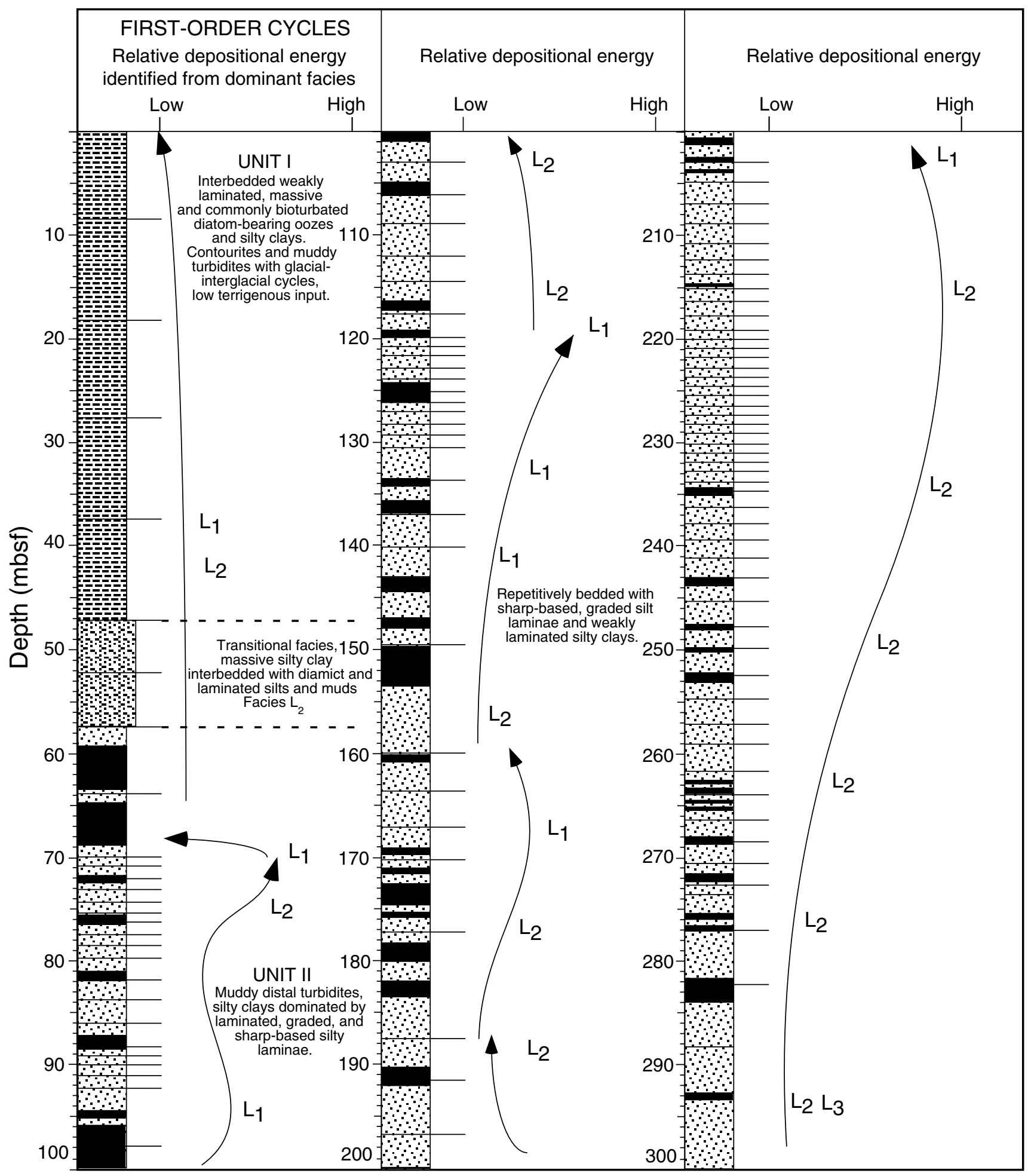




\section{C.J. Pudsey}

NeOgene GLACIATION Record

Figure F3. A. Biogenic silica percentage for the upper $300 \mathrm{~m}$ of Site 1095. Inset boxes show parts of the section illustrated in more detail in F5, p. 19, F6, p. 21, F7, p. 23, and F8, p. 25. B. Sand percentage for the upper $300 \mathrm{~m}$ of Site 1095.

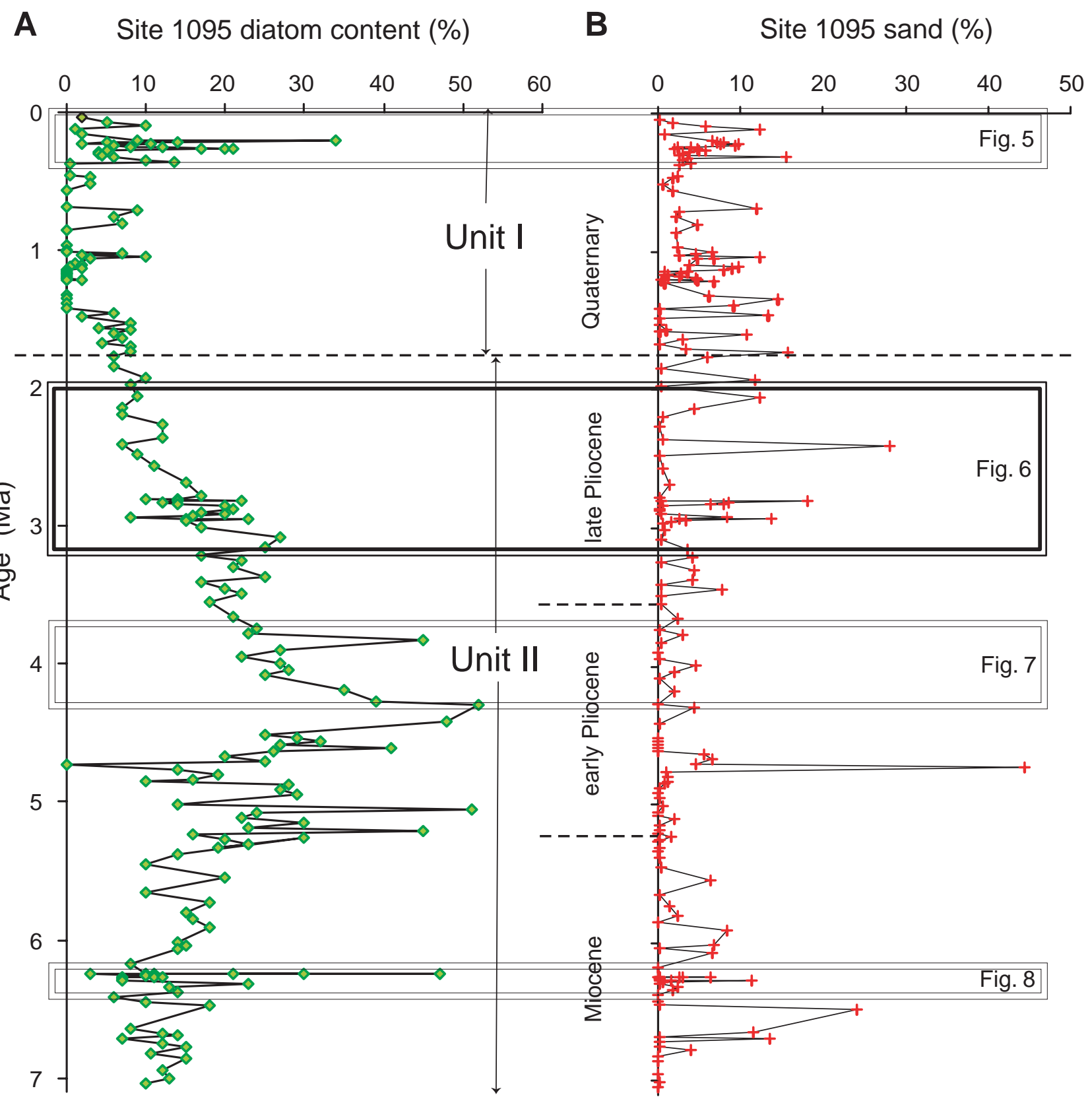


Figure F4. Fine fraction particle size distribution for the upper $300 \mathrm{~m}$ of Site 1095. A. Sand-silt-clay (red-yellow-brown) as weight percentage. B. Median diameter in $\phi$ units, with average of $10 \phi$ (Pleistocene, 0-1.8 Ma) and $9.7 \phi$ (Pliocene and Miocene) indicated by dashed lines. C. Modal diameter in $\phi$ units (about one-third of samples do not have a well-defined mode, hence missing values). D. Sorting (black), dimensionless ratio. E. Skewness, dimensionless.

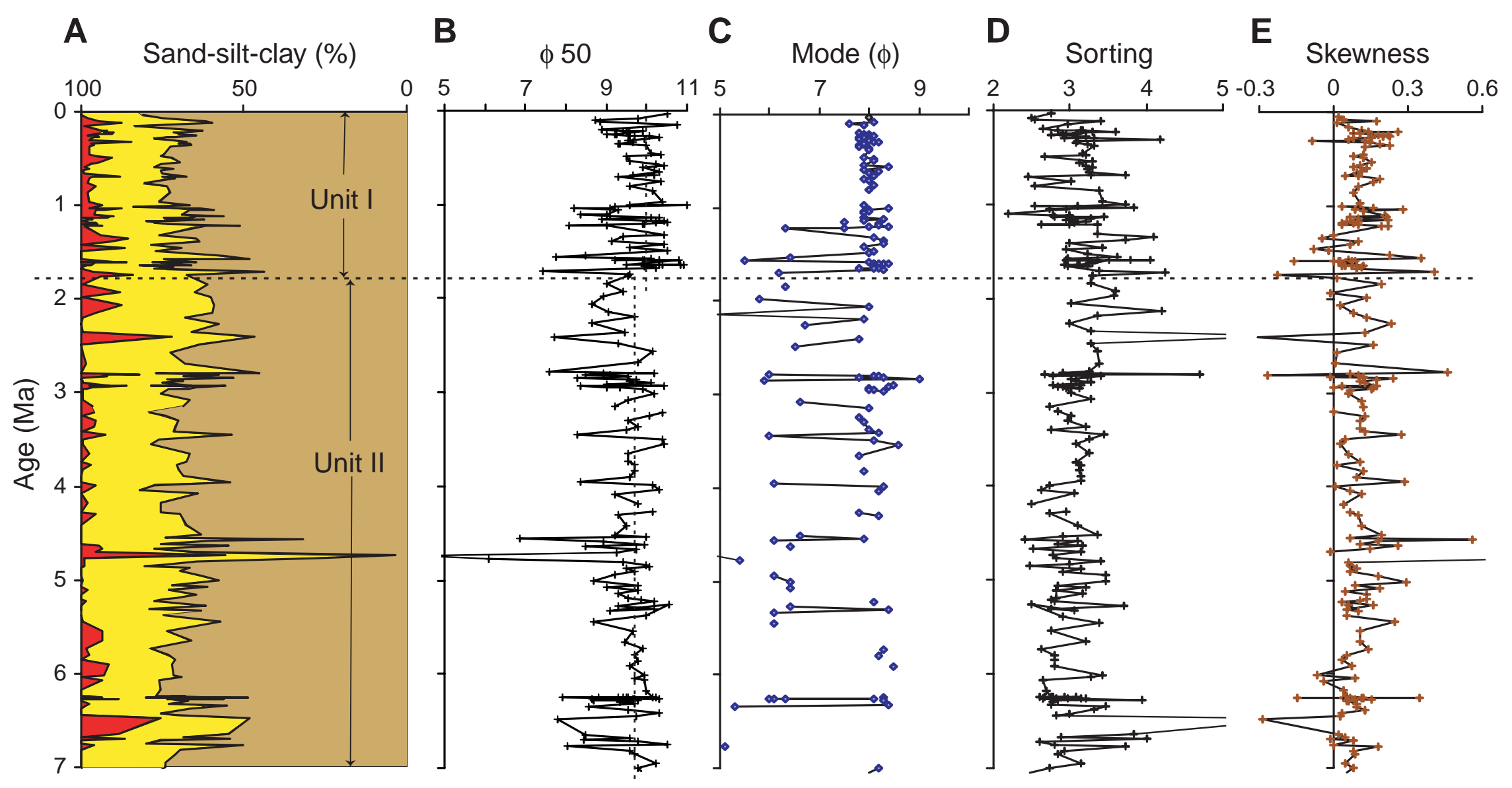




\section{C.J. Pudsey}

NeOgene GLaCiation Record

Figure F5. Late Quaternary, 0-0.4 Ma (0-10 mbsf). The core log at the left shows the occurrence of bioturbated and laminated intervals. Warm isotope stages are delineated using the presence of diatoms, supplemented by the occurrence of the diatom Hemidiscus karstenii at $4.6 \mathrm{mbsf}$ (Stage 7; Shipboard Scientific Party, 1999) and the radiolarian Stylatractus universus at $7.84 \mathrm{mbsf}$ (Stage 11; this work). Magnetic susceptibility is low in Stages 5, 7, and 9 and higher and more variable in Stages 2-4, 6, and 10 downward. Color parameter $a^{*}$ is higher in the brown intervals of Stages 5, 7, and the upper part of 9 .

The grain-size pattern is less obviously cyclic at this distal site with a low sedimentation rate than at core sites higher on the drift (Pudsey and Camerlenghi, 1998). Most samples have a weak mode near the silt/ clay boundary of $4 \mu \mathrm{m}(8 \phi)$. Glacial samples consistently have less coarse silt than interglacial samples (compare histograms at 0.9 and $4.49 \mathrm{mbsf}$ ). The three sand histograms at $2.29 \mathrm{mbsf}$ (Stage 2), 4.59 mbsf (Stage 7), and 4.94 mbsf (Stage 8) show that coarse, unsorted sand occurs in glacials as well as interglacials.

Spectral analysis, shown in the lower panel, reveals weak peaks of power spectral density at 73, 9.6, and 5.2 $\mathrm{ka}$ in magnetic susceptibility and $50.6 \mathrm{ka}$ in chromaticity $\mathrm{a}^{*}$. The units of power spectral density are for color, (chromaticity) ${ }^{2}$ per cycle per $0.1 \mathrm{~m}$, and for magnetic susceptibility, (SI units) ${ }^{2}$ per cycle per $0.1 \mathrm{~m}$. (Figure shown on next page.) 
C.J. Pudsey

NeOgene GLaCiation Record

Figure F5 (continued). (Caption shown on previous page).

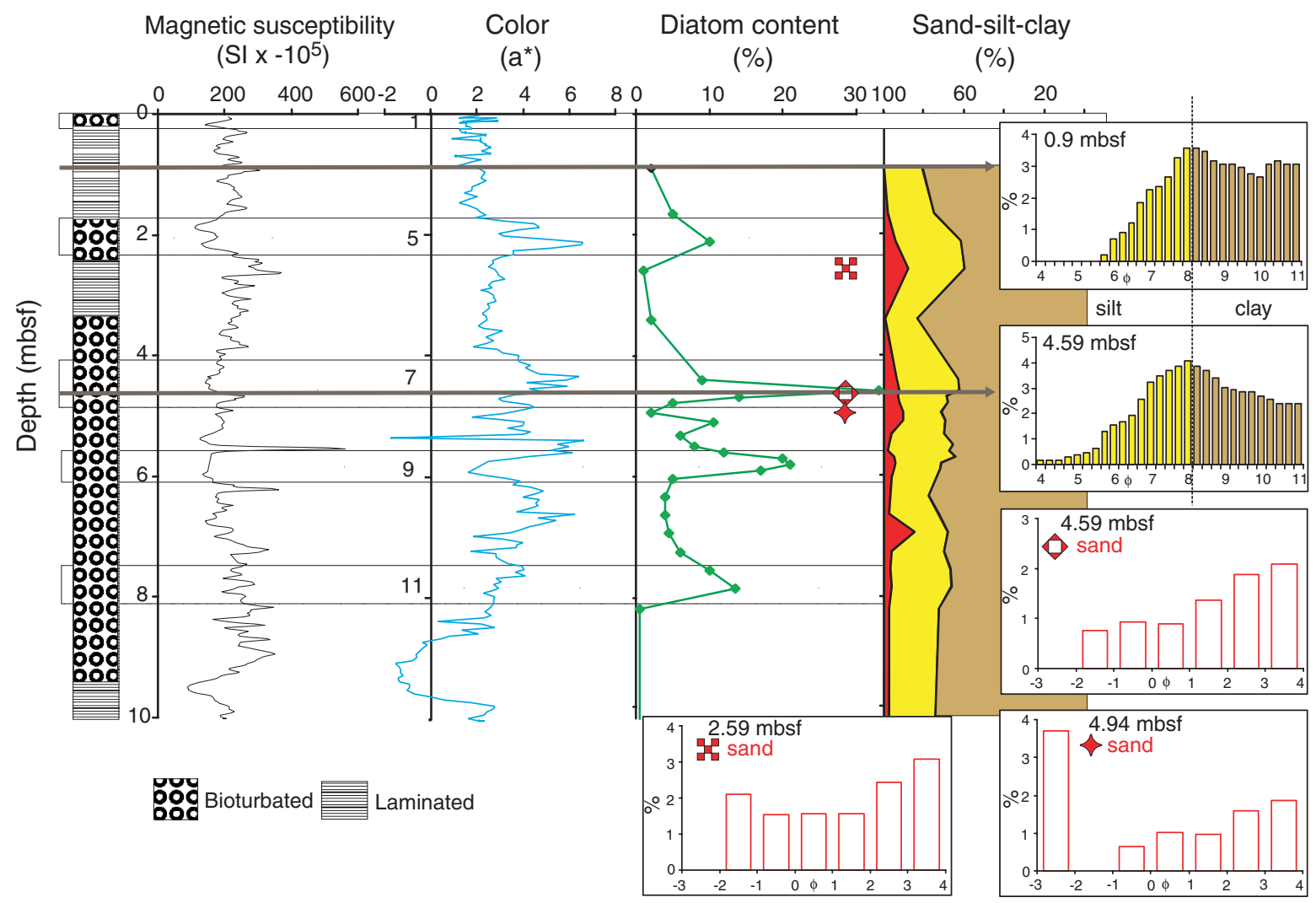

Spectral analysis

Magnetic susceptibility (Cycles per $0.1 \mathrm{~m}$ )

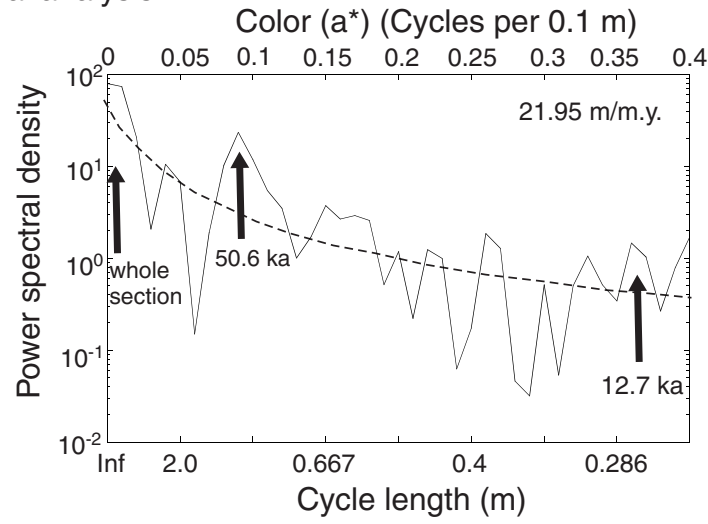




\section{C.J. Pudsey}

Figure F6. Late Pliocene, 2-3 Ma (65-85 mbsf). The core log at the left shows the occurrence of bioturbated and laminated intervals. Inclined bedding from 81.7 to 82.4 mbsf may result from slumping. Magnetic susceptibility shows, to the human eye, cyclicity at approximately a 100-k.y. period (11 peaks in $1.1 \mathrm{~m} . \mathrm{y}$.; peaks and troughs marked by black and gray curve symbols). Color parameter a* shows 7 peaks in 1.1 m.y., with troughs of varying thickness (blue curve symbols). This corresponds to a period of $160 \mathrm{k} . \mathrm{y}$. Bioturbated units occur at the top of each trough; they constitute the whole of the thin troughs at 74.8 and 77 mbsf. The color cycles do not show a consistent phase relationship to magnetic susceptibility.

Spectral analysis, shown in the middle panel, reveals peaks of power spectral density at $74,35,19,12.3$, and $5.8 \mathrm{ka}$ in magnetic susceptibility and 221 and $17.2 \mathrm{ka}$ in color parameter $\mathrm{a}^{*}$.

The lower part of diagram shows part of Core 178-1095A-10H demonstrating relationship of diatom percentage and grain size to bioturbated and laminated facies, with representative grain-size frequency histograms. (Figure shown on next page.) 
C.J. Pudsey

NeOgene GLaCiation Record

Figure 6 (continued). (Caption shown on previous page).

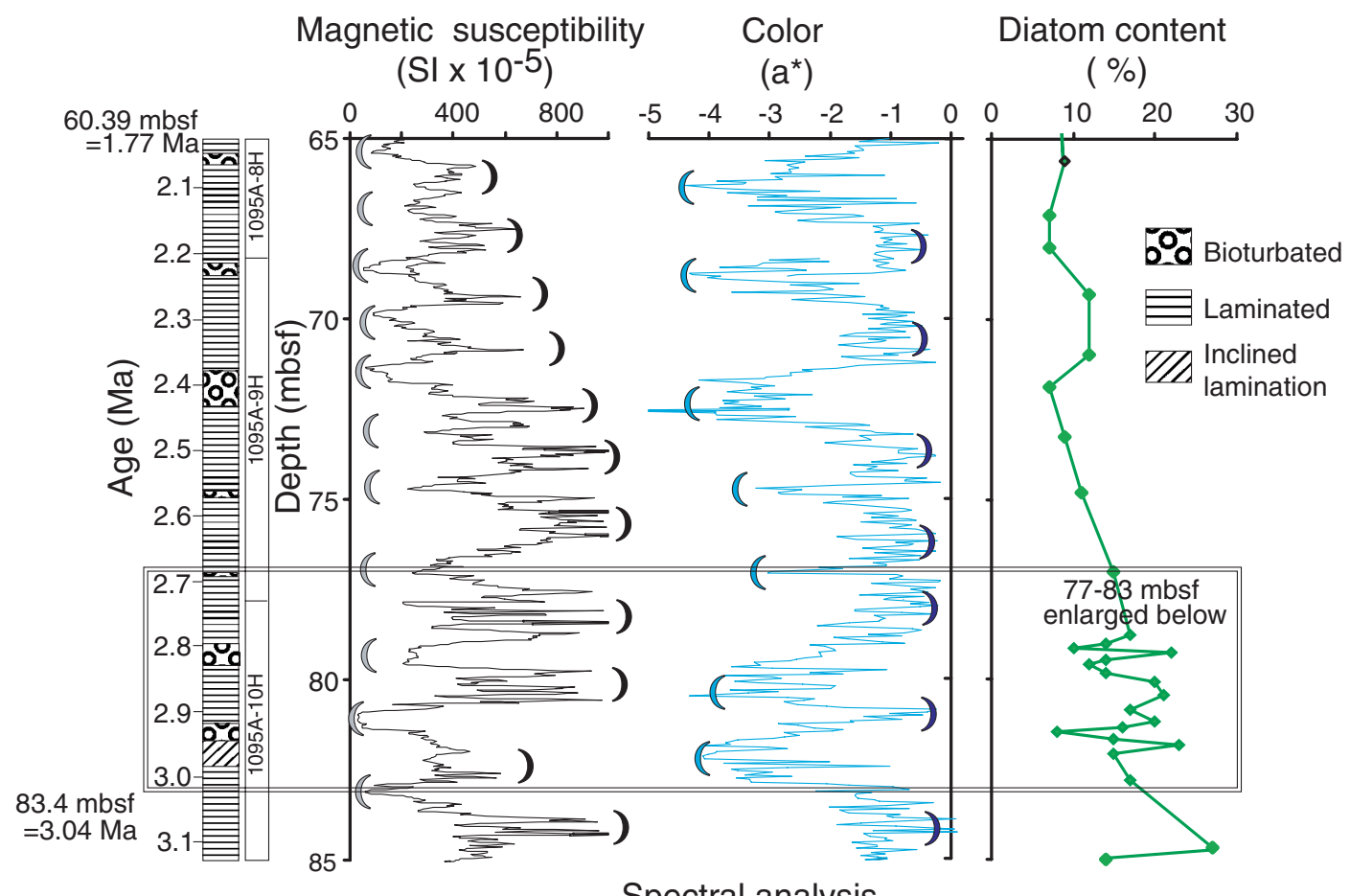

Spectral analysis

Magnetic susceptibility (Cycles per $0.1 \mathrm{~m}$ )

Color (a*) (Cycles per $0.1 \mathrm{~m}$ )
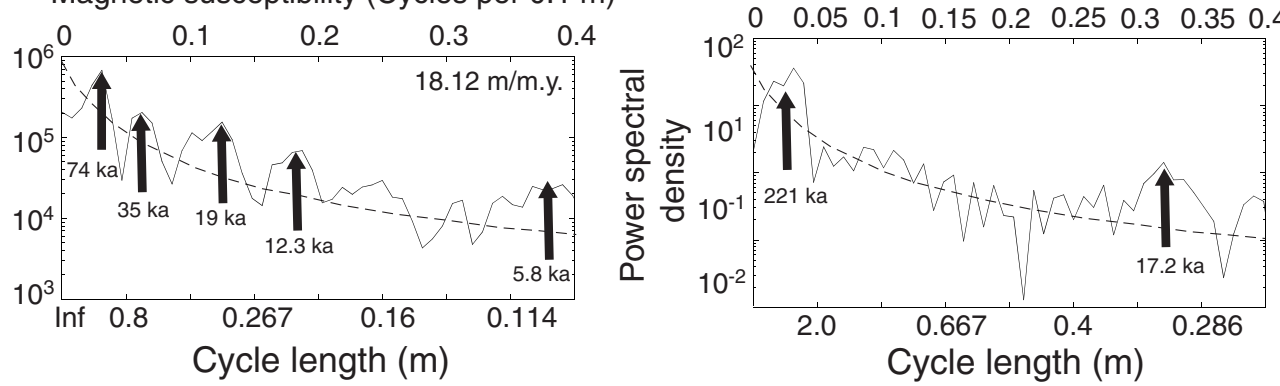

Diatom content Sand-silt-clay

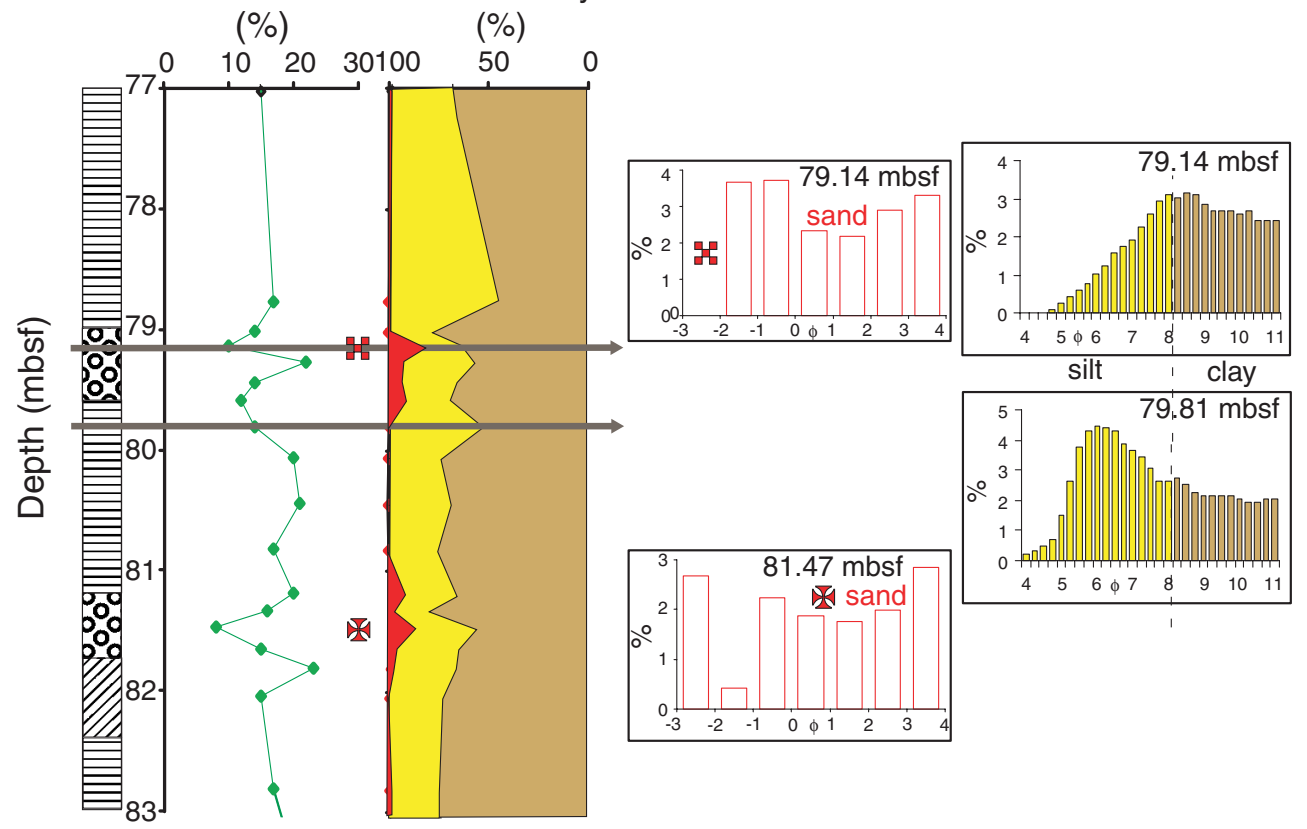




\section{C.J. Pudsey}

Figure F7. Early Pliocene, 3.7-4.3 Ma (105-130 mbsf). The core log at the left shows the occurrence of bioturbated and laminated intervals. Magnetic susceptibility and color $\left(\mathrm{a}^{*}\right)$ both have lower values in the bioturbated intervals (bioturbated intervals are greener and laminated intervals grayer). Intervals containing lighter-colored silts at 110-110.4 and 127-127.9 mbsf have low susceptibility. Fine fraction size distributions from the laminated facies typically have a mode in the silt range (histogram at $116.51 \mathrm{mbsf}$ ). The bioturbated facies contains poorly sorted sand and very little silt (histograms at $118.34 \mathrm{mbsf}$ ).

Spectral analysis, shown in the lower panel, reveals weak peaks of power spectral density at $63.5,19,5.6$, and $4.0 \mathrm{ka}$ in magnetic susceptibility and $140,12.5,7.3$, and $6.2 \mathrm{ka}$ in chromaticity $\mathrm{a}^{*}$. (Figure shown on next page.) 
Figure 7 (continued). (Caption shown on previous page).

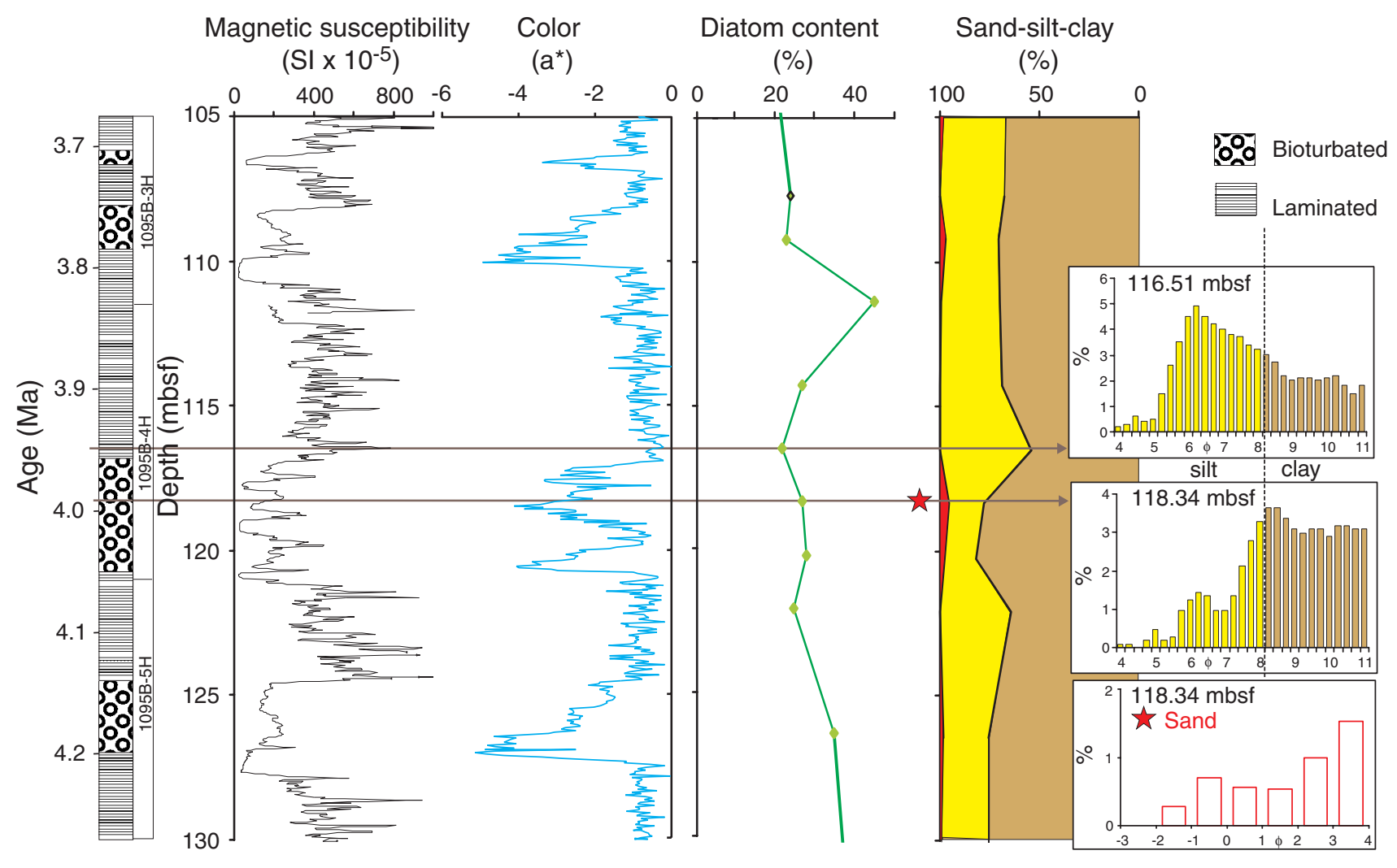

Spectral analysis

Magnetic susceptibility (Cycles per $0.1 \mathrm{~m}$ )

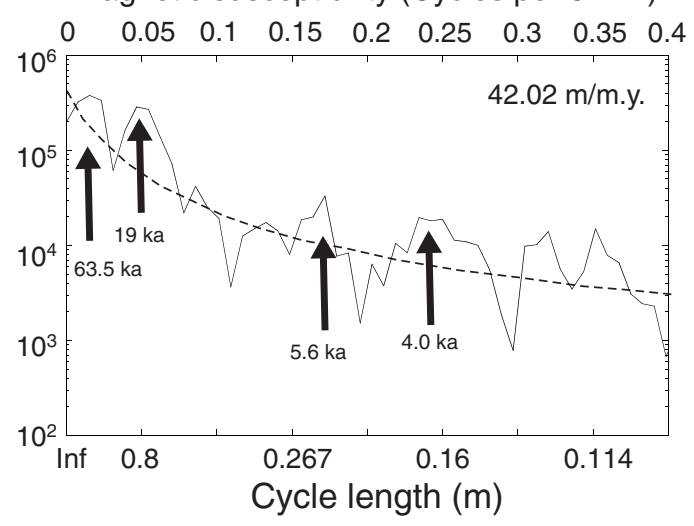

Color $\left(\mathrm{a}^{*}\right)$ (Cycles per $0.1 \mathrm{~m}$ )

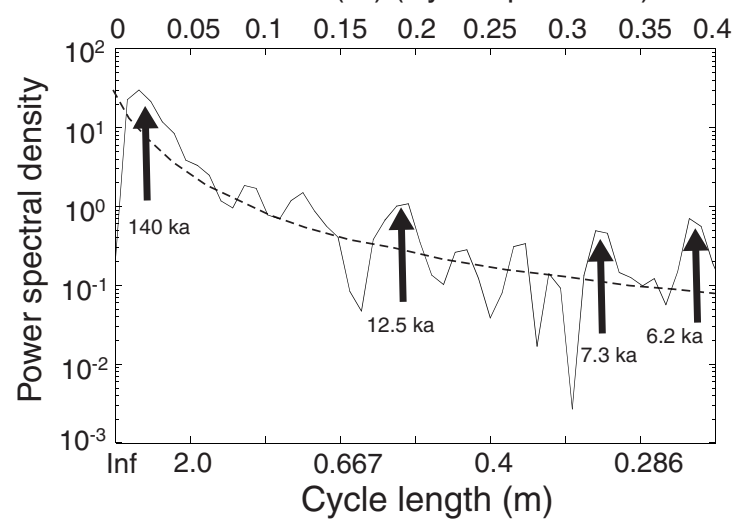


Figure F8. Late Miocene, 6.23-6.36 Ma (234-245 mbsf). The core log at the left shows the occurrence of bioturbated (circular ornament) and laminated intervals. Magnetic susceptibility and color $\left(\mathrm{a}^{*}\right)$ both have lower values in the bioturbated intervals (bioturbated intervals are greener and laminated intervals grayer). The sandy, low-a* interval just above 240 mbsf is not bioturbated (from shipboard core description and inspection of core photograph) and does not have high diatom content. Spectral analysis was not performed for this interval because there is a change in sedimentation rate in the middle.

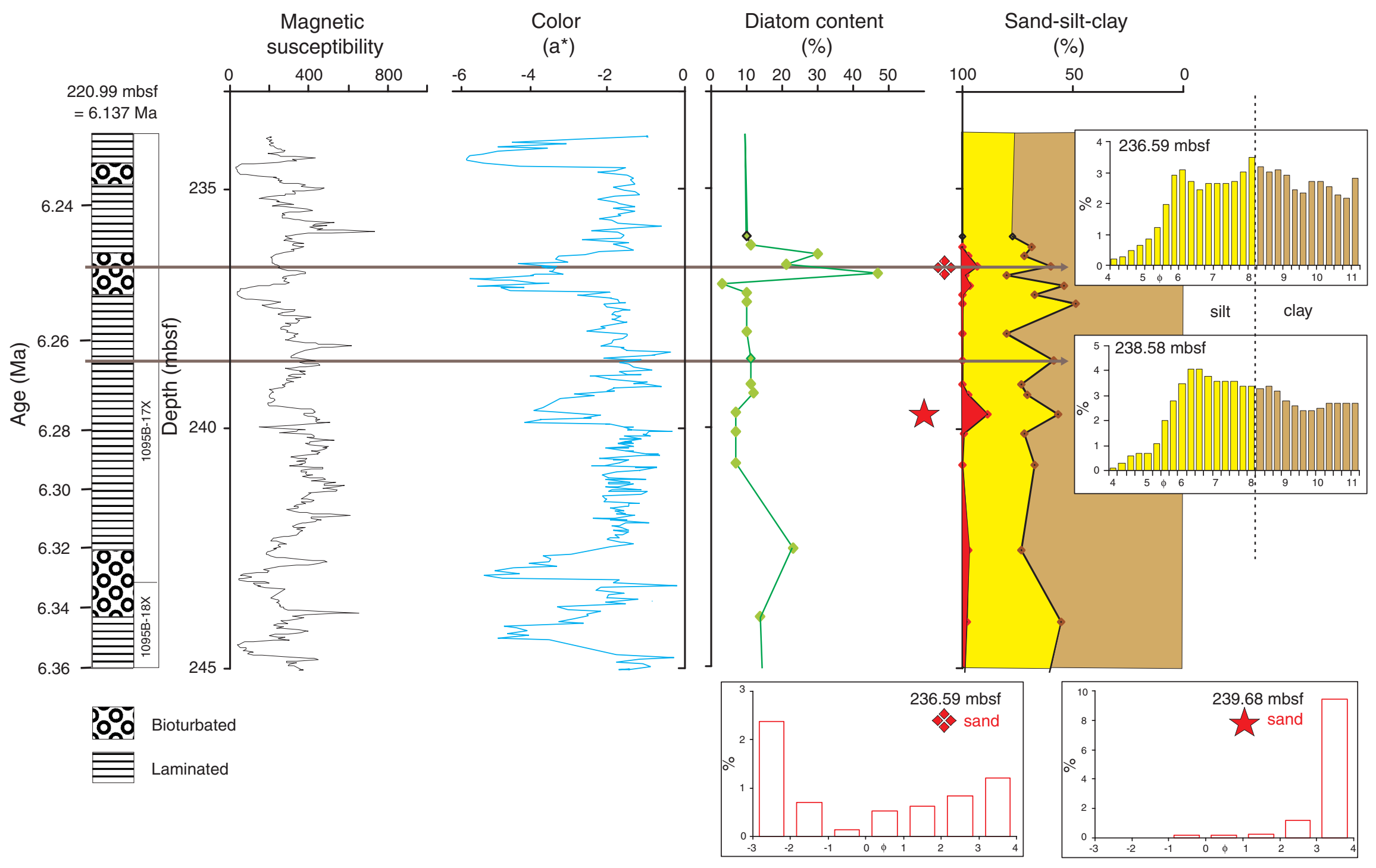

